\title{
Važnost motiva za postignućem i moći za rad na rukovodećoj poziciji, plaću i intrinzičnu motivaciju za posao
}

\author{
Mitja Ružojčić ${ }^{1}$, Zvonimir Galić1 i Nataša Trojak ${ }^{2}$ \\ ${ }^{1}$ Sveučilište u Zagrebu, Filozofski fakultet, Odsjek za psihologiju, Zagreb, Hrvatska \\ ${ }^{2}$ Visoko učilište Algebra, Zagreb, Hrvatska
}

\begin{abstract}
Sažetak
U ovom je istraživanju vraćen fokus na dvije osobine koje su prije pojave petofaktorskog modela ličnosti, uz inteligenciju, smatrane ključnim odrednicama radnih i karijernih postignuća, motiv za postignućem i motiv za moći. Provjereno je hoće li ovi motivi predviđati tri važna radna ishoda: rad na rukovodećoj poziciji, plaću i intrinzičnu motivaciju za posao, povrh osobina petofaktorskog modela. Pri tome je rad na rukovodećoj poziciji operacionaliziran zauzimanjem posla na višim razinama organizacijske hijerarhije; plaća kao visina mjesečne neto plaće, a intrinzična motivacija za posao izmjerena je upitničkom mjerom. Istraživanje je provedeno na 160 zaposlenika različitih hrvatskih radnih organizacija, čiji su podaci prikupljeni internetskim anketnim upitnikom. Korelacijske i regresijske analize pokazale su da su motivi za postignućem i moći važna determinanta ovih radnih ishoda te ih objašnjavaju bolje od osobina petofaktorskog modela. Pri tome je motiv za postignućem bio važnija determinanta intrinzične motivacije za posao, a motiv za moći rukovodeće pozicije i plaće. Ovi nalazi pokazuju kako aspekti ličnosti koji su uže povezani s radnim kontekstom, kao što su motiv za postignućem i motiv za moći, imaju dodatnu vrijednost te bi ih se trebalo uzeti $u$ obzir zajedno sa širokim osobinama petofaktorskog modela u svrhu što boljeg predviđanja radnih ishoda.
\end{abstract}

Ključne riječi: motiv za postignućem, motiv za moći, petofaktorski model ličnosti, rukovodeća pozicija, plaća, intrinzična motivacija za posao

\section{Uvod}

Istraživanja važnosti ne-kognitivnih odrednica radnih ishoda $u$ okviru psihologije rada i organizacijske psihologije imaju dugu tradiciju, pri čemu je u početku pozornost najviše pridavana motivima za postignućem, moći i afilijacijom (McClelland i Burnham, 2003). Međutim, 70-ih se godina prošlog stoljeća smanjilo

Mitja Ružojčić, Odsjek za psihologiju, Filozofski fakultet, Sveučilište u Zagrebu, Ivana Lučića 3, 10000 Zagreb, Hrvatska. E-pošta: mruzojci@ffzg.hr

Rad je djelomično financirala Hrvatska zaklada za znanost u sklopu projekta 6719 Implicitna ličnost i radno ponašanje. 
zanimanje za istraživanja motiva uslijed kritika osobinskog pristupa (Mischel, 1968), a oživljavanje je zanimanja za ličnost potaknuto razvojem petofaktorskog modela ličnosti (Costa i McCrae, 1992; Goldberg, 1990). Otada je ova taksonomija dominantno korištena $u$ istraživanjima ličnosti u psihologiji rada $i$ organizacijskoj psihologiji, ali i u psihologiji općenito (Kanfer, Frese i Johnson, 2017). Ovo potvrđuje i niz metaanalitičkih studija koje pokazuju kako je ličnost opisana petofaktorskim modelom važna determinanta niza radnih ishoda uključujući radnu uspješnost (Barrick, Mount i Judge, 2001), zadovoljstvo poslom (Judge, Heller i Mount, 2002), motivaciju za rad (Judge i Ilies, 2002) i karijernu uspješnost (Ng, Eby, Sorensen i Feldman, 2005; Roberts, Kuncel, Shiner, Caspi i Goldberg, 2007).

Međutim, ni petofaktorski pristup nije bez kritika, među kojima se često ističe njegova prevelika opširnost i heterogenost zbog koje ne zahvaća dovoljno detaljno neke osobine ličnosti koje bi mogle pridonijeti predviđanju važnih radnih ishoda (Hough, 1992; Wu i LeBreton, 2011). Stoga smo u ovom istraživanju odlučili vratiti fokus na dvije osobine koje su prije pojave petofaktorskog modela, uz inteligenciju, smatrane ključnim odrednicama radnih i karijernih postignuća, motiv za postignućem i motiv za moći. ${ }^{1}$

Motiv za postignućem često se smatra konstruktom koji najbolje odražava individualne razlike u motivaciji (Sackett i sur., 2017). Osobe s visokim motivom za postignućem pokazuju snažnu želju za preuzimanjem odgovornosti za obavljanjem zadataka, postavljaju si izazovne, ali dostižne ciljeve, a prilikom obavljanja zadataka poticaj nalaze u prirodi samog zadatka ili u mogućnosti dokazivanja da su ga sposobni izvršiti (McClelland, 1987; Steinmann, Ötting i Maier, 2016). S druge strane, osobe s visokim motivom za moći imaju snažnu potrebu za upravljanjem i usmjeravanjem ljudi i događaja, stoga češće zauzimaju rukovoditeljske pozicije u organizaciji (Yukl, 2008).

Smatramo kako su ova dva motiva i dalje veoma bitna u radnom kontekstu te da mogu znatno pridonijeti objašnjavanju i razumijevanju triju radnih ishoda: intrinzične motivacije za posao te dva najčešće korištena objektivna indikatora karijerne uspješnosti (Heslin, 2005; Ng i sur., 2005) - zauzimanja rukovodeće pozicije na poslu i visine mjesečne plaće. U nastavku ćemo prvo izložiti nalaze vezane uz češće istražen odnos - vezu dva motiva s navedenim indikatorima karijerne uspješnosti. Nakon toga objasnit ćemo zašto smatramo da su dva motiva važna i za intrinzičnu motivaciju za posao, što je odnos koji, po našim saznanjima, do sada nije detaljnije istraživan.

\footnotetext{
${ }^{1}$ Iako se motivi razlikuju od osobina ličnosti jer proizlaze iz temeljnih ljudskih potreba i zahvaćaju dublje strukture ličnosti (Winter, John, Stewart, Klohnen i Duncan, 1998), u psihologiji rada i organizacijskoj psihologiji oni se često svrstavaju u istu kategoriju individualnih razlika kao i osobine ličnosti - razlike u ličnosti (Kanfer i sur., 2017; Sackett, Lievens, Van Iddekinge i Kuncel, 2017; Yukl, 2008). Iz ovog razloga, ali i zbog toga što smo $\mathrm{u}$ ovom istraživanju i motive $\mathrm{i}$ osobine petofaktorskog modela zahvatili upitnicima samoprocjene, motive tretiramo kao pokazatelje individualnih razlika u aspektima ličnosti.
} 


\section{Važnost motiva za postignućem i moći za zauzimanje rukovodeće pozicije i visinu plaće}

Brojna su istraživanja pokazala kako je visok motiv za postignućem povezan sa zauzimanjem rukovodeće pozicije i visinom plaće. Tako je longitudinalna studija McClellanda i Boyatzisa (1982) pokazala da je motiv za postignućem povezan s napredovanjem u organizacijskoj hijerarhiji 16 godina kasnije. Također, u još jednoj longitudinalnoj studiji McClelland i Franz (1992) pokazali su da je snaga motiva za postignućem izmjerena u 31. godini života predviđala visinu plaće 10 godina kasnije. Osim dvije navedene studije koje demonstriraju dugotrajne efekte motivacije za postignućem, McClelland (1987) u svojoj knjizi "Human Motivation" navodi niz drugih istraživanja koja jasno pokazuju da je motiv za postignućem važan za ova dva objektivna indikatora karijernog uspjeha. Uz nalaze koji izravno povezuju motiv za postignućem s rukovodećom pozicijom i plaćom Judge, Bono, Ilies i Gerhardt (2002) su u svojoj metaanalizi odnosa osobina ličnosti i vođenja u organizacijama pokazali kako je faceta savjesnosti težnja k postignuću bolje predviđala prepoznavanje pojedinca kao vođe i uspješnost u rukovođenju od samog faktora savjesnosti. Također, metaanaliza Dudley, Orvis, Lebieckog i Cortine (2006) pokazala je da je ista faceta predviđala radnu uspješnost i posvećenost poslu bolje od globalnog faktora savjesnosti. S obzirom na to da su veća uspješnost i posvećenost poslu svakako bitni faktori za postizanje karijerne uspješnosti izražene kroz plaću i napredovanje, ovi su nalazi snažan argument i za važnost motiva za postignućem za objektivnu karijernu uspješnost, i to povrh osobina petofaktorskog modela.

Što se tiče motiva za moći, niz istraživanja očekivano potvrđuje njegovu vezu sa zapošljavanjem na višim razinama organizacijske hijerarhije (npr. Howard i Bray, 1988; McClelland i Boyatzis, 1982; Stahl, 1983). Uz to, metaanaliza Judgea i suradnika (2002) pokazala je da dominantnost, faceta ekstraverzije koja se znatno preklapa s motivom za moći, predviđa prepoznavanje osobe kao vođe i uspjeh $\mathrm{u}$ rukovođenju. Pri tome, ona to čini bolje od ekstraverzije, koja je od velikih pet osobina ličnosti najvažnija za uspjeh u rukovođenju. Iako je manji broj istraživanja ispitivao vezu motiva za moći i visine plaće, očekivano je da će ona također biti pozitivna s obzirom na to da je i zauzimanje rukovodeće pozicije povezano s višom plaćom (npr. Ng i sur., 2005; Seibert, Crant i Kraimer, 1999), a izraženi motiv za moći povezuje se i s prikupljanjem obilježja prestiža (McClelland, 1987). U prilog tome ide i nalaz Judgea i suradnika (Judge, Cable, Boudreau i Bretz, 1995), koji su na velikom uzorku rukovoditelja pokazali kako je ambicioznost, definirana kao želja za napredovanjem u organizaciji, predviđala godišnju plaću. Također, Frieze, Olson, Murrell i Selvan (2006) su pokazali da su radne vrijednosti koje su povezane s motivom za moći predviđale visinu plaće sudionika više od 15 godina kasnije. 


\section{Važnost motiva za postignućem i moći za intrinzičnu motivaciju za posao}

I dok su veze motiva za postignućem i moći sa zauzimanjem rukovodeće pozicije i visinom plaće dosta jasno utvrđene, važnost dvaju motiva za intrinzičnu motivaciju za posao rijetko je istraživana. Ipak, s obzirom na to da osobe s visokim motivom za postignućem potiče sama priroda zadatka i dokazivanje da ga mogu izvršiti, logično je očekivati da će pokazivati i više razine intrinzične motivacije za posao, tj. obavljati posao zbog same prirode posla, zato što im je zanimljiv i predstavlja im užitak (Gagne i Deci, 2005). U skladu su s time Carbonneau, Vallerand i Lafreniere (2012) na uzorku studenata pokazali kako motiv za postignućem predviđa intrinzičnu motivaciju u različitim situacijama. Uz to, pokazuje se kako postavljanje ciljeva koji su usmjereni na razvoj kompetencija i svladavanje zadataka rezultira intrinzičnom motivacijom prilikom obavljanja zadatka (Elliot i Harackiewicz, 1996; Rawsthorne i Elliot, 1999), a upravo ovakve ciljeve u većoj mjeri postavljaju pojedinci s visokim motivom za postignućem (Bipp, Steinmayr i Spinath, 2008). I konačno, istraživanja pokazuju da aktivnosti koje pružaju optimalnu razinu izazova dovode do najviših razina intrinzične motivacije (Gagne i Deci, 2005), a zahtjevni, ali dostižni ciljevi koje postavljaju pojedinci s visokim motivom za postignućem mogu se okarakterizirati upravo kao "optimalno izazovni".

Za razliku od motiva za postignućem motiv za moći ne bi trebao biti izravna odrednica intrinzične motivacije za posao. Međutim, kao što je i ranije navedeno, osobe s visokim motivom za moći imaju snažnu preferenciju prema poslovima na rukovodećim pozicijama (Howard i Bray, 1988; McClelland i Boyatzis, 1982). Razlog je tome to što samo takvi poslovi mogu zadovoljiti njihovu potrebu za upravljanjem i vođenjem drugih (Miner, 1978). Zato se može pretpostaviti da će osobama s visokim motivom za moći upravo ovakvi poslovi biti zanimljivi i pružati užitak jer sama priroda posla na rukovodećoj poziciji odražava potrebe koje proizlaze iz motiva za moći.

\section{Cilj istraživanja}

U ovom smo istraživanju htjeli provjeriti važnost motiva za postignućem i motiva za moći za zauzimanje rukovodeće pozicije, visinu plaće i intrinzičnu motivaciju za posao na uzorku hrvatskih radnika. Ovaj rad ima nekoliko doprinosa za područje psihologije rada i organizacijske psihologije.

Najvećim doprinosom ovog rada smatramo ispitivanje odnosa motiva za postignućem i moći s intrinzičnom motivacijom za posao jer ove veze u psihologiji rada do sada nisu detaljnije istraživane. Ipak, s obzirom na ranije navedene nalaze, čini se da bi motiv za postignućem trebao biti važna determinanta intrinzične 
motivacije za posao dok bi motiv za moći trebao biti važan za intrinzičnu motivaciju samo kod poslova na rukovodećim pozicijama.

Također, iako ranije navedena istraživanja već sada pružaju snažne indikacije da dva motiva igraju važnu ulogu u determiniranju zauzimanja rukovodeće pozicije i visine plaće kao indikatora uspjeha u karijeri, u literaturi nismo pronašli nijednu studiju koja je ispitivala njihov doprinos u odnosu na trenutno dominantni petofaktorski model ličnosti. Najbliže tome su metaanalize Judgea i suradnika (2002) i Dudley i suradnika (2006) koje su uspoređivale učinke faceta petofaktorskog modela koje se preklapaju s ova dva motiva s učincima velikih pet faktora na iste kriterijske varijable. Međutim, Judge i suradnici predviđali su prepoznavanje vođe i uspješnost vođenja, a eksplicitno navode da nisu uzimali u obzir studije koje operacionaliziraju zauzimanje rukovodeće pozicije kao oblik karijerne uspješnosti (str. 769). Uz to, mjere kriterija i uzorci koje su uvrstili u metaanalizu nisu nužno bili vezani uz radni kontekst (npr. procjene učitelja o rukovodećem ponašanju učenika u razredu). Također, mjere motiva za moći klasificirali su i kao ekstraverziju i kao dominantnost, a mjere motiva za postignućem i kao savjesnost i kao težnju za postignućem. Dudley i suradnici su, s druge strane, promatrali učinke na radno ponašanje, a ne krajnje ishode rada, kao što je karijerna uspješnost ili motivacija za rad. Osim toga, u svojoj su metaanalizi zahvatili samo osobinu savjesnosti i njezine facete.

Motiv za postignućem u osnovi je težnja za razvojem vještina i uspješnim izvršavanjem zadataka, a motiv za moći težnja za kontroliranjem ljudi i događaja, što su potrebe koje odrasli ljudi mogu primarno zadovoljiti kroz posao. Stoga smatramo kako su ova dva motiva znatno uže vezana za radni kontekst te bi zato trebali bolje predviđati radne ishode od širokih osobina petofaktorskog modela ličnosti.

Uz ova dva opća doprinosa jedan je specifičan doprinos vezan za hrvatski kontekst jer je ovo prvo istraživanje koje je ispitalo važnost ličnosti za objektivno odmjerenu karijernu uspješnost. Jedino istraživanje u hrvatskom kontekstu o učinku ličnosti na karijerni uspjeh do sada su provele Maslić Seršić i Tomas (2014), u kojem je ličnost operacionalizirana preko temeljnih samoevaluacija (Erez i Judge, 2003), a karijerna uspješnost bila je samoprocijenjena. Većina je istraživanja ove tematike provedena u zapadnim zemljama, koje karakterizira tržište rada u snažnijoj mjeri utemeljeno na meritokratskim principima te koja se razlikuju od tranzicijskih zemalja poput Hrvatske u radnim uvjetima i odnosu prema radnicima (Šverko i Galić, 2014). Mislimo da je i zato važno provjeriti hoće li se nalazi opisani u uvodu vezani uz odnos motiva s rukovodećom pozicijom i plaćom replicirati i na hrvatskom uzorku.

U skladu smo s navedenim u istraživanju postavili sljedeće hipoteze:

H1. Osobe s višim motivom za postignućem i višim motivom za moći češće će se nalaziti na rukovoditeljskim pozicijama i imat će više plaće.

H2a. Osobe s višim motivom za postignućem imat će višu razinu intrinzične motivacije za posao. 
H2b. Zauzimanje rukovodeće pozicije moderirat će efekt motiva za moći na intrinzičnu motivaciju za posao i to tako što će visok motiv za moći biti povezan s intrinzičnom motivacijom za posao samo kod pojedinaca koji rade na rukovodećim pozicijama.

Prilikom testiranja naših hipoteza kontrolirat ćemo povezanost objektivnih indikatora karijerne uspješnosti i intrinzične motivacije za posao s osobinama petofaktorskog modela, kao dominantne taksonomije ličnosti.

\section{Metoda}

\section{Postupak i sudionici}

Podaci su prikupljeni internetskim anketnim upitnikom na prigodnom uzorku od 168 zaposlenika različitih hrvatskih radnih organizacija. Sudionici su regrutirani na tri načina: 1) objavljen je poziv na istraživanje s poveznicom na anketni upitnik na Facebookovoj stranici Katedre za psihologiju rada i ergonomiju Odsjeka za psihologiju Filozofskog fakulteta u Zagrebu; 2) osobno su zamoljeni kolege i poznanici da ispune upitnik i/ili proslijede poveznicu na upitnik svojim radnim kolegama; 3) poveznica s pozivom za sudjelovanje $u$ istraživanju poslana je na eadresar jednoga hrvatskoga poslijediplomskog programa za izobrazbu menadžera. Kao nagradu za sudjelovanje sudionicima je ponuđena izrada njihova profila ličnosti na temelju petofaktorskog modela. Ako su htjeli dobiti svoj profil ličnosti, sudionici su na kraju anketnog upitnika trebali ostaviti svoju e-adresu. Pri tome je jasno navedeno kako njihova e-adresa neće biti korištena u bilo kakve daljnje svrhe niti proslijeđena trećoj strani te su po slanju profila ličnosti e-adrese izbrisane iz baze podataka.

Kako bi se osiguralo da svi sudionici motivirano ispune upitnik, među čestice upitnika ubačeno je i nekoliko kontrolnih pitanja, kojima se željelo identificirati sudionike koji su odgovarali po slučaju, zapravo ne čitajući pitanja. Primjer je kontrolnog pitanja: "Ovim pitanjem provjeravamo preskačete li neke tvrdnje. Odaberite najnižu opciju". Na ovaj je način iz uzorka isključeno osam sudionika, pa je konačni uzorak činilo 160 sudionika.

Od konačnih 160 sudionika $78.8 \%$ činile su žene, a prosječna je dob uzorka bila 36.42 godine $(S D=7.64)$. Sudionici su bili uglavnom visoko obrazovani, pri čemu je njih $61.3 \%$ bilo visoke stručne spreme, dok ih je $24.4 \%$ završilo poslijediplomski studij. Samo je 7.5\% sudionika bilo srednje stručne spreme. U prosjeku, sudionici su imali 11.54 godine ukupnoga radnog staža $(S D=7.15)$ i 7.16 godina staža u trenutnoj organizaciji $(S D=6.42)$. Polovica je sudionika $(53.8 \%)$ radila u privatnom, a $40 \%$ u javnom sektoru (6.3\% nije jasno naznačilo u kojem su sektoru zaposleni). Uzorak je bio ravnomjerno raspoređen s obzirom na veličinu radnih organizacija u kojima su sudionici zaposleni, pa je $26.3 \%$ sudionika bilo zaposleno u organizacijama s više od 
500 zaposlenih, $19.4 \%$ u organizacijama sa 100 do 500 zaposlenika, $30.6 \%$ u organizacijama s 10 do 100 zaposlenih i $21.3 \%$ u organizacijama s manje od 10 zaposlenika. Većina je sudionika bila zaposlena na neodređeno vrijeme $(80 \%)$ dok ih je $14.4 \%$ bilo zaposleno pod ugovorom na određeno. Četvrtina je sudionika (23.8\%) radila na rukovoditeljskoj poziciji, kao voditelj odjela, direktor ili član uprave. Također, skoro je četvrtina sudionika (22.5\%) imala mjesečnu plaću višu od 10000 kn. Plaću u rasponu od 7001 do 10000 kn imalo je 24.4\% sudionika, a 27.5\% imalo je plaću u rasponu od 5501 do $7000 \mathrm{kn}$.

\section{Mjerni instrumenti}

Motivi za postignućem i moći izmjereni su Objedinjenim skalama motiva (engl. The Unified Motive Scales (UMS); Schönbrodt i Gerstenberg, 2012). Svaku supskalu čini šest čestica. Na obje se supskale procjenjuje važnost određenih ciljeva na ljestvici od 0 (nije mi važan) do 5 (izrazito mi je važan), dok se za polovicu čestica supskale motiva za moći slaganje procjenjuje na ljestvici od 0 (izrazito se ne slažem) do 5 (izrazito se slažem). Cronbach $\alpha$ pouzdanost skale motiva za postignuće bila je .83, a primjeri su čestica: "(Koliko Vam je važno) Osobno obavljati rad visoke kvalitete" i "(Koliko Vam je važno) Neprekidno se poboljšavati". Pouzdanost skale motiva za moći bila je .87, a primjeri su čestica: "(Koliko Vam je važno) Imati mogućnost utjecaja (na druge)" i "Težim prema pozicijama na kojima imam autoritet".

Zauzimanje rukovoditeljske pozicije i plaću sudionika operacionalizirali smo dvama pitanjima u kojima smo pitali sudionike da označe razinu koju zauzimaju u organizacijskoj hijerarhiji i visinu svoje mjesečne neto plaće. Da bi sudionik bio označen rukovoditeljem, trebao je biti barem voditelj odjela, poslovnice ili područja. Voditelji timova, projekata i poslovođe u radnoj grupi nisu označeni kao rukovoditelji zbog njihovih znatno manjih ovlasti u delegiranju zadataka i raspoređivanju resursa te ograničenog broja podređenih.

Kako bi se smanjio broj sudionika koji ne žele odgovoriti na pitanje o mjesečnoj plaći (Dillman, 2007), opcije su odgovora na to pitanje svedene na pet kategorija: 1) manja od $3500 \mathrm{kn}, 2$ ) od 3501 do $5500 \mathrm{kn}, 3) 5501$ do $7000 \mathrm{kn}$, 4) 7001 do 10 $000 \mathrm{kn}, 5)$ viša od $10000 \mathrm{kn}$. Uz to, s obzirom na osjetljivost pitanja, dodana je i opcija "Ne želim odgovoriti".

Za mjerenje intrinzične motivacije za posao korištena je supskala intrinzične motivacije iz Multidimenzionalne skale radne motivacije (engl. Multidimensional Work Motivation Scale (MWMS); Gagne i sur., 2015), na kojoj sudionici procjenjuju razloge ulaganja truda na trenutnom poslu na ljestvici od 1 (uopće ne) do 7 (u potpunosti da). Ovu skalu čine tri čestice: ("Zato jer se zabavljam radeći svoj posao", "Zato jer je ono što radim na poslu uzbudljivo" i "Zato jer je posao koji radim zanimljiv"), a Cronbach $\alpha$ pouzdanost iznosi .88 . 
Osobine petofaktorskog modela ličnosti izmjerene su upitnikom IPIP-20 (Donnellan, Oswald, Baird i Lucas, 2006), koji zahvaća svaki od pet faktora ličnosti $\mathrm{s}$ četiri čestice na ljestvici od 1 (posve netočno) do 5 (posve točno). Cronbach $\alpha$ pouzdanosti skala upitnika kretale su se od .69 za skalu ugodnosti do .79 za skalu ekstraverzije.

\section{Rezultati}

U Tablici 1. prikazana je deskriptivna statistika i korelacije između varijabli korištenih u istraživanju. Budući da je plaća, iako se radi o kontinuiranoj varijabli, operacionalizirana kroz pet ordinalnih kategorija, za nju su izračunati poliserijalni korelacijski koeficijenti, koji bi trebali biti precizniji pokazatelj povezanosti za ovako izmjerene kontinuirane varijable (Drasgow, 1988).

Motivi su imali značajne povezanosti s objektivnim indikatorima karijerne uspješnosti, pri čemu je, djelomično u skladu s očekivanjima, motiv za postignućem bio povezan samo s mjesečnom plaćom $\left(r_{p s}=.19, p<.05\right)$, dok je motiv za moći bio značajno povezan i s rukovoditeljskom pozicijom $(r=.25, p<.01)$ i s mjesečnom plaćom $\left(r_{p s}=.28, p<.01\right)$. Dakle, sudionici s višim razinama obaju motiva imali su veću plaću, dok su se sudionici sa snažnijim motivom za moći češće nalazili i na rukovoditeljskoj poziciji. Iznenađujuće, oba su motiva, a ne samo motiv za postignućem, bila pozitivno povezana s intrinzičnom motivacijom za posao. Ipak, motiv za postignućem imao je znatno jaču vezu s intrinzičnom motivacijom $(r=.40$, $p<.01)$ od motiva za moći $(r=.17, p<.05)$. Dodatno, motivi su međusobno bili pozitivno povezani $(r=.44, p<.01)$, a bili su pozitivno povezani i s većinom osobina ličnosti. Tako su i motiv za postignućem i motiv za moći bili pozitivno povezani s ekstraverzijom, ugodnosti i otvorenosti prema iskustvima (korelacije između .22 do .38 ), a motiv za postignućem bio je povezan i s emocionalnom stabilnosti $(r=.17, p$ $<.05)$.

Osobine petofaktorskog modela ličnosti uglavnom nisu bile značajno povezane s korištenim objektivnim indikatorima karijerne uspješnosti, pa su tako jedino ekstraverzija $\left(r_{p s}=.20, p<.05\right)$ i emocionalna stabilnost $\left(r_{p s}=.17, p<.05\right)$ bile povezane s višom mjesečnom plaćom. $\mathrm{S}$ druge strane, sve su osobine ličnosti osim savjesnosti bile pozitivno povezane s intrinzičnom motivacijom (.20 do .27). Dakle, ekstravertiraniji, ugodniji, emocionalno stabilniji i otvoreniji pojedinci pokazali su više razine intrinzične motivacije za posao. 
Tablica 1.

Deskriptivni podaci i korelacije među korištenim varijablama $(n=160)$

\begin{tabular}{|c|c|c|c|c|c|c|c|c|c|c|}
\hline Varijabla & $\begin{array}{c}M \\
(S D)\end{array}$ & 1. & 2. & 3. & 4. & 5. & 6. & 7. & 8. & 9. \\
\hline 1. Ekstraverzija & $\begin{array}{c}3.40 \\
(0.78) \\
\end{array}$ & - & & & & & & & & \\
\hline 2. Ugodnost & $\begin{array}{c}4.05 \\
(0.56)\end{array}$ & $.34^{* *}$ & - & & & & & & & \\
\hline 3. Savjesnost & $\begin{array}{c}3.48 \\
(0.82) \\
\end{array}$ & -.11 & -.04 & - & & & & & & \\
\hline $\begin{array}{l}\text { 4. Emocionalna } \\
\text { stabilnost }\end{array}$ & $\begin{array}{c}3.23 \\
(0.83) \\
\end{array}$ & $.22^{* *}$ & .14 & .15 & - & & & & & \\
\hline 5. Otvorenost & $\begin{array}{c}3.88 \\
(0.73)\end{array}$ & $.17^{*}$ & $.31^{* *}$ & -.11 & .04 & - & & & & \\
\hline $\begin{array}{l}\text { 6. Motiv za } \\
\text { postignućem }\end{array}$ & $\begin{array}{c}3.62 \\
(0.72)\end{array}$ & $.22^{* *}$ & $.36^{* *}$ & -.02 & $.17^{*}$ & $.42^{* *}$ & - & & & \\
\hline 7. Motiv za moći & $\begin{array}{c}2.72 \\
(0.92)\end{array}$ & $.38^{* *}$ & $.26^{* *}$ & .03 & .12 & $.26^{* *}$ & $.44^{* * *}$ & - & & \\
\hline $\begin{array}{l}\text { 8. Rukovoditeljska } \\
\text { pozicija }^{1}\end{array}$ & $\begin{array}{c}0.24 \\
(0.43) \\
\end{array}$ & .13 & -.01 & -.06 & -.07 & -.02 & .12 & $.25^{* *}$ & - & \\
\hline 9. Mjesečna plaća ${ }^{2}$ & $\begin{array}{c}2.52 \\
(1.14) \\
\end{array}$ & $.20^{*}$ & .09 & .14 & $.17^{*}$ & -.04 & $.19^{*}$ & $.28^{* *}$ & $.55^{* *}$ & - \\
\hline $\begin{array}{l}\text { 10. Intrinzična } \\
\text { motivacija za posac }\end{array}$ & $\begin{array}{c}5.34 \\
(1.34) \\
\end{array}$ & $.21^{* *}$ & $.26^{* *}$ & -.07 & $.27^{* *}$ & $.20^{*}$ & $.40^{* *}$ & $.17^{*}$ & $.19^{*}$ & $.17^{*}$ \\
\hline
\end{tabular}

Legenda: ${ }^{1} 0=$ nije rukovoditelj, $1=$ rukovoditelj; ${ }^{2} 0=\operatorname{manje~od~} 3500 \mathrm{kn}, 1=3501$ do $5500 \mathrm{kn}, 2=$ 5501 do $7000 \mathrm{kn}, 3=7001$ do $10000 \mathrm{kn}, 4=$ više od $10000 \mathrm{kn}$, za veze s mjesečnom plaćom prikazani su poliserijalni koeficijenti korelacija; ${ }^{*} p<.05 ;{ }^{* *} p<.01$.

Kako bi se provjerila dodana valjanost motiva za predviđanje rukovoditeljske pozicije na poslu, provedena je logistička regresijska analiza. U prvom su koraku uvrštene osobine ličnosti iz petofaktorskog modela, a u drugom koraku motivi.

Rezultati su logističke regresijske analize za predviđanje rukovoditeljske pozicije prikazani u Tablici 2. Iako je u prvom koraku ekstraverzija značajno predviđala rukovodeću poziciju $(B=0.59, O R=1.80, p<.05)$, u drugom je koraku jedini značajan prediktor bio motiv za moći $(B=0.67, O R=1.96, p<.01)$. U skladu s time, motivi su pokazali dodanu valjanost objašnjavajući veći postotak varijance rukovoditeljske pozicije (Nagelkerke $\Delta R^{2}=.10, p<.01$ ) u odnosu na osobine petofaktorskog modela (Nagelkerke $\Delta R^{2}=.05, p>.05$ ). Ipak, ovo se može pripisati prvenstveno motivu za moći jer motiv za postignućem nije značajno predviđao rukovodeću poziciju. 
Tablica 2.

Rezultati logističke regresijske analize za predviđanje rukovoditeljske pozicije (0 = nije rukovoditelj, 1 = rukovoditelj; $n=155$ )

\begin{tabular}{lcccc}
\hline & \multicolumn{2}{c}{1 korak } & \multicolumn{2}{c}{ 2. korak } \\
\hline Prediktor & \multicolumn{1}{c}{$B(S E)$} & $O R^{l}$ & $B(S E)$ & $O R^{l}$ \\
\hline Ekstraverzija & $0.59(0.30)^{*}$ & $1.80^{*}$ & $0.34(0.31)$ & 1.40 \\
Ugodnost & $-0.23(0.38)$ & 0.79 & $-0.47(0.41)$ & 0.63 \\
Savjesnost & $-0.08(0.24)$ & 0.93 & $-0.14(0.25)$ & 0.87 \\
Emocionalna stabilnost & $-0.31(0.24)$ & 0.74 & $-0.32(0.25)$ & 0.73 \\
Otvorenost & $-0.15(0.28)$ & 0.86 & $-0.45(0.32)$ & 0.64 \\
Motiv za postignućem & & & $0.32(0.36)$ & 1.38 \\
Motiv za moći & \multicolumn{3}{c}{$0.67(0.27)^{*}$} & $1.96^{*}$ \\
\hline Nagelkerke $R^{2}$ & \multicolumn{3}{c}{$.15^{*}$} \\
\hline Nagelkerke $\Delta R^{2}$ & \multicolumn{3}{c}{$.10^{* *}$} \\
\hline
\end{tabular}

Legenda: ${ }^{1}$ OR $=$ odds ratio $;{ }^{*} p<.05 ;{ }^{* *} p<.01$.

Za predviđanje je mjesečne plaće provedena linearna regresijska analiza na temelju poliserijalnih korelacija prediktora s mjesečnom plaćom i Pearsonovih koeficijenata korelacije između prediktora. Ponovno, u prvom su koraku uvrštene osobine petofaktorskog modela, a u drugom koraku motivi.

Od osobina petofaktorskog modela samo je ekstraverzija zadržala značajnost u prvom koraku $(B=0.19, p<.05)$, ali je i ona prestala biti značajan prediktor dodavanjem motiva u model $(B=0.12, p>.05)$. Motivi su objasnili dodatni postotak varijance u mjesečnoj plaći u odnosu petofaktorski model $\left(\Delta R^{2}=.07, p<.01\right)$, ali je samo viši motiv za moći bio značajan prediktor $(B=0.22, p<.05)$.

Tablica 3.

Rezultati linearne regresijske analize za predviđanje mjesečne plaće $(0=$ manje od $3500 \mathrm{kn}$, $4=$ više od $10000 \mathrm{kn} ; \mathrm{n}=147$ )

\begin{tabular}{lcccc}
\hline & \multicolumn{2}{c}{ 1. korak } & \multicolumn{2}{c}{ 2. korak } \\
\hline Prediktor & $B(S E)$ & $\beta$ & $B(S E)$ & $\beta$ \\
\hline Ekstraverzija & $0.19(0.09)^{*}$ & $.19^{*}$ & $0.12(0.09)$ & .12 \\
Ugodnost & $0.04(0.09)$ & .04 & $-0.01(0.09)$ & -.01 \\
Savjesnost & $0.14(0.08)$ & .14 & $0.12(0.08)$ & .12 \\
Emocionalna stabilnost & $0.11(0.08)$ & .11 & $0.10(0.08)$ & .10 \\
Otvorenost & $-0.08(0.08)$ & -.08 & $-0.16(0.09)$ & -.16 \\
Motiv za postignućem & & $0.11(0.10)$ & .11 \\
Motiv za moći & \multicolumn{3}{c}{$0.22(0.09)^{*}$} & $.22^{*}$ \\
\hline$R^{2}$ & \multicolumn{2}{c}{$.08^{*}$} & \multicolumn{2}{c}{$.15^{* *}$} \\
\hline Korigirani $R^{2}$ & .05 & \multicolumn{3}{c}{$.07^{* * *}$} \\
\hline$\Delta R^{2}$ & $.08^{*}$
\end{tabular}

Legenda: ${ }^{*} p<.05 ;{ }^{* *} p<.01$. 
Kako bi se provjerila dodana valjanost motiva u odnosu na osobine ličnosti za predviđanje intrinzične motivacije na poslu, provedena je linearna regresijska analiza. U prvom su koraku kao prediktori dodane osobine ličnosti petofaktorskog modela, u drugom su koraku dodani motivi, a u trećem je koraku dodan podatak o razini koju pojedinac zauzima u organizaciji i njegova interakcija s motivom za moći. Kako bi se izbjegla multikolinearnost, varijable rukovoditeljske pozicije i motiva za moći standardizirane su prije računanja interakcijskog termina (Aiken i West, 1991). Rezultati regresijske analize za predviđanje intrinzične motivacije na poslu prikazani su u Tablici 4. U regresijskoj su analizi od osobina petofaktorskog modela samo emocionalna stabilnost $(B=.39, p<.01)$ i ugodnost $(B=.40, p<.05)$ zadržali značajnost, s time da je dodavanjem motiva u model ugodnost također prestala biti značajan prediktor $(B=.26, p>.05)$. Što se tiče motiva dodanih u drugom koraku, oni su objasnili dodatni postotak varijance u odnosu na petofaktorski model ličnosti $\left(\Delta R^{2}=.08, p<.01\right) \mathrm{i}$ visok motiv za postignućem značajno je predviđao intrinzičnu motivaciju na poslu $(B=.61, p<.01)$. S druge strane, motiv za moći nije zadržao značajnost nakon što smo kontrolirali ostale prediktore $(B=-.04, p>.05)$, niti je zauzimanje rukovoditeljske pozicije moderiralo njegov efekt na intrinzičnu motivaciju za posao $(B=-.03, p>.05)$. Time je $\mathrm{H} 2$ djelomično potvrđena jer je motiv za postignućem predviđao intrinzičnu motivaciju za posao povrh osobina petofaktorskog modela (H2a), no motiv za moći nije predviđao intrinzičnu motivaciju u interakciji sa zauzimanjem rukovoditeljske pozicije (H2b).

Ukupno gledano, korelacijske i regresijske analize pokazale su da su motivi za moći i postignućem važni za objašnjavanje radnih ishoda jer su predvidjeli i objektivne pokazatelje karijerne uspješnosti i intrinzičnu motivaciju za posao, i to povrh osobina ličnosti petofaktorskog modela. ${ }^{2}$

Tablica 4.

Rezultati linearne regresijske analize za predviđanje intrinzične motivacije za posao $(n=$ 153)

\begin{tabular}{lcccccc}
\hline & \multicolumn{2}{c}{ 1. korak } & \multicolumn{2}{c}{ 2. korak } & \multicolumn{2}{c}{ 3. korak } \\
\hline Prediktor & $B(S E)$ & $\beta$ & $B(S E)$ & $\beta$ & $B(S E)$ & $\beta$ \\
\hline Ekstraverzija & $0.13(0.14)$ & .08 & $0.12(0.14)$ & .07 & $0.09(0.14)$ & .05 \\
Ugodnost & $0.40(0.20)^{*}$ & $.17^{*}$ & $0.26(0.19)$ & .11 & $0.30(0.19)$ & .13 \\
Savjesnost & $-0.15(0.12)$ & -.10 & $-0.15(0.12)$ & -.09 & $-0.13(0.12)$ & -.08 \\
Emocionalna & $0.39(0.12)^{* *}$ & $.25^{* * *}$ & $0.33(0.12)^{* * *}$ & $.21^{* *}$ & $0.37(0.12)^{* *}$ & $.24^{* * *}$ \\
stabilnost & & & & & & \\
Otvorenost & $0.24(0.14)$ & .13 & $0.05(0.15)$ & .03 & $0.09(0.15)$ & .05 \\
$\begin{array}{l}\text { Motiv za } \\
\text { postignućem }\end{array}$ & & & $0.61(0.16)^{* *}$ & $.33^{* *}$ & $0.58(0.16)^{* *}$ & $.31^{* * *}$ \\
\hline
\end{tabular}

\footnotetext{
${ }^{2}$ Broj sudionika u regresijskim analizama (Tablice 2.-4.) razlikuje se jer nismo uspjeli dobiti podatak o razini u organizacijskoj hijerarhiji, visini plaće i intrinzičnoj motivaciji za posao od svih sudionika.
} 


\begin{tabular}{|c|c|c|c|c|c|c|}
\hline & \multicolumn{2}{|c|}{ 1. korak } & \multicolumn{2}{|c|}{ 2. korak } & \multicolumn{2}{|c|}{ 3. korak } \\
\hline Prediktor & $B(S E)$ & $\beta$ & $B(S E)$ & $\beta$ & $B(S E)$ & $\beta$ \\
\hline Motiv za moći & & & $-0.04(0.12)$ & -.02 & $-0.10(0.12)$ & -.07 \\
\hline $\begin{array}{l}\text { Rukovoditeljska } \\
\text { pozicija }^{1}\end{array}$ & & & & & $0.60(0.23)^{*}$ & $.20^{*}$ \\
\hline $\begin{array}{l}\text { Rukovoditeljska } \\
\text { pozicija x Motiv za } \\
\text { moći }\end{array}$ & & & & & $-0.03(0.09)$ & -.02 \\
\hline$R^{2}$ & \multicolumn{2}{|c|}{$.17^{* *}$} & \multicolumn{2}{|c|}{$.25^{* *}$} & \multicolumn{2}{|c|}{$.28^{* *}$} \\
\hline Korigirani $R^{2}$ & \multicolumn{2}{|c|}{.14} & \multicolumn{2}{|c|}{.21} & \multicolumn{2}{|c|}{.24} \\
\hline$\Delta R^{2}$ & \multicolumn{2}{|c|}{$.17^{* *}$} & \multicolumn{2}{|c|}{$.08^{* *}$} & \multicolumn{2}{|c|}{$.03^{*}$} \\
\hline
\end{tabular}

Legenda: ${ }^{1} 0=$ nije rukovoditelj, $1=$ rukovoditelj; ${ }^{*} p<.05 ;{ }^{* *} p<.01$.

\section{Rasprava}

Pojavom je petofaktorskog modela ličnosti važnost motiva za postignućem i moći za različite radne ishode znatno rjeđe istraživana. U ovom smo istraživanju htjeli vratiti fokus na ova dva motiva i provjeriti njihovu važnost za zauzimanje rukovodeće pozicije, visinu plaće i intrinzičnu motivaciju za posao na uzorku hrvatskih radnika. Pri tome, središnjim doprinosom ovoga rada smatramo ispitivanje do sada nedovoljno istražene veze dvaju motiva s intrinzičnom motivacijom za posao. Također, važne doprinose predstavljaju i istraživanje dodane valjanosti motiva za postignućem i moći za rukovodeću poziciju i plaću povrh osobina ličnosti petofaktorskog modela te činjenica da je ovo prvo istraživanje koje je ispitivalo ove odnose u hrvatskom kontekstu.

Iako su naše hipoteze djelomično potvrđene jer je samo motiv za moći predviđao objektivne indikatore karijerne uspješnosti (H1), a samo motiv za postignućem intrinzičnu motivaciju za posao povrh osobina petofaktorskog modela ličnosti (H2), naše je istraživanje pokazalo kako ova dva motiva mogu biti koristan prediktor radnih ishoda. Naime, na bivarijatnoj su razini oba motiva bila značajno povezana s intrinzičnom motivacijom i jednim od objektivnih indikatora karijerne uspješnosti, mjesečnom plaćom, dok je motiv za moći, uz to, bio povezan i s drugim indikatorom karijerne uspješnosti, zauzimanjem rukovoditeljske pozicije. Uz to, motivi su za sva tri radna ishoda imali dodanu prediktivnu valjanost povrh osobina ličnosti petofaktorskog modela, objašnjavajući time $7-10 \%$ dodatne varijance. Također, za sva je tri kriterija uvijek jedan od motiva bio važniji prediktor od velikih pet faktora jer je motiv za moći u odnosu na ostale prediktore imao najviše korelacije $\mathrm{s}$ rukovoditeljskom pozicijom i mjesečnom plaćom, a motiv za postignućem $\mathrm{s}$ intrinzičnom motivacijom za posao.

Kao glavni doprinos ovog rada ističe se ispitivanje veze dvaju motiva $\mathrm{s}$ intrinzičnom motivacijom za posao. Očekivano, nalazi upućuju na to da je motiv za postignućem bio značajno povezan $\mathrm{s}$ intrinzičnom motivacijom za posao, što i ne 
čudi s obzirom na to da intrinzična motivacija uključuje motiviranost samom prirodom posla (Gagne i Deci, 2005), a upravo osobe visokog motiva za postignućem poticaj za obavljanje radnih zadataka nalaze u prirodi, odnosno karakteristikama zadataka (McClelland, 1987).

Što se, pak, tiče motiva za moći, nismo imali razloga očekivati da će općenito biti povezan $\mathrm{s}$ intrinzičnom motivacijom za posao. Iako je dobivena niska, ali značajna korelacija $\mathrm{s}$ intrinzičnom motivacijom, uvrštavanjem je u regresijsku analizu motiva za moći zajedno s motivom za postignućem ova povezanost izgubila na statističkoj značajnosti. Međutim, očekivali smo da će pojedinci s visokim motivom za moći biti intrinzično motivirani za posao ako su zaposleni na rukovodećoj poziciji jer sama priroda rukovodećeg posla uključuje upravljanje i usmjeravanje drugih. Ipak, ovu hipotezu nismo potvrdili. Moguće je da osobe s visokim motivom za moći kod rukovoditeljskog posla ne motivira sama priroda radnih zadataka, nego doživljaj moći koji proizlazi iz posla koji uključuje upravljanje drugima i daje im legitiman autoritet, kontrolu nad dodjeljivanjem nagrada i mogućnost upravljanja informacijama (tzv. pozicijska moć; Yukl i Falbe, 1991).

Motiv za moći pokazao se važnijim za objektivne indikatore karijerne uspješnosti nego za intrinzičnu motivaciju, što nije iznenađujuće jer su veze s plaćom i, pogotovo, rukovodećom pozicijom na temelju teorije i prijašnjih istraživanja očekivane (npr. Frieze i sur., 2006; Judge i sur., 1995; Yukl, 2008). S druge strane, motiv za postignućem imao je niske korelacije s objektivnim indikatorima karijerne uspješnosti pri čemu je korelacija sa zauzimanjem rukovodeće pozicije bila neznačajna, a uvrštavanjem u regresijski model zajedno s motivom za moći veza motiva za postignućem s plaćom također je postala neznačajna. Međutim, istraživanja pokazuju kako osobe s visokim motivom za postignućem u većoj mjeri postavljaju ciljeve usmjerene na učenje, koji se tiču razvoja vlastitih kompetencija, nego ciljeve usmjerene na ishode, koji uključuju dokazivanje vlastitih sposobnosti drugima (Bipp i sur., 2008; Phillips i Gully, 1997). Stoga je vjerojatnije da osobe visokog motiva za postignućem za procjenu vlastite karijerne uspješnosti koriste subjektivne izvore koji ne zahtijevaju usporedbu s drugima, kao što je zadovoljstvo vlastitim učinkom ili zadovoljstvo poslom. Prema nekim se konceptualizacijama (Heslin, 2005) doživljaj smisla i ispunjenosti koje pojedinac dobiva od posla, koji je vrlo sličan intrinzičnoj motivaciji za posao, također može smatrati oblikom (subjektivne) karijerne uspješnosti. Uz to, neznačajna se povezanost s rukovodećom pozicijom također može objasniti i načinom na koji smo operacionalizirali rukovodeću poziciju. Naime, rukovoditelj je u našem istraživanju bio, u najmanju ruku, voditelj odjela, poslovnice ili područja. Ovo su rukovodeće pozicije viših razina, a pokazuje se da je motiv za postignućem važan za napredovanje, ali samo na nižim razinama rukovođenja, u kojima je promaknuće u većoj mjeri posljedica individualnih postignuća. Na višim razinama rukovoditeljski posao zahtijeva više utjecanja i usmjeravanja drugih ljudi, pa stoga motiv za moći ima veću važnost (McClelland i Boyatzis, 1982), kao što je i naše istraživanje pokazalo. 
Uz navedeno, važno je spomenuti i da je ovo prvo istraživanje koje je ispitalo važnost ličnosti za objektivno odmjerenu karijernu uspješnost u hrvatskom kontekstu. Nalazi vezani za motiv za moći replicirali su nalaze prijašnjih studija, provedenih većinom u zapadnim kulturama, i pokazali da su unatoč razlikama između hrvatske tranzicijske ekonomije i razvijenih zapadnih ekonomija individualne razlike $u$ motivima važne za zauzimanje rukovodeće pozicije i visinu plaće. Uz to, moguće je i da su neke od karakteristika hrvatskog društva utjecale na rezultate koji se nisu replicirali na hrvatskom uzorku. Na primjer, moguće je da karakteristike osoba s visokim motivom za postignućem, kao što su veća želja za preuzimanjem odgovornosti za obavljanje zadataka i postavljanje izazovnih ciljeva, u hrvatskim radnim organizacijama nisu nagrađene i višim plaćama. U prilog ovome idu i nalazi Europskog istraživanja o radnim uvjetima (Eurofund, 2015), prema kojima samo $41 \%$ Hrvata smatra da je na svom poslu plaćeno primjereno svom trudu i postignućima te smo prema tome na začelju Europske unije (EU). Za usporedbu, u cijeloj EU 51\% radnika smatra da je plaćeno primjereno, a u razvijenim zemljama poput Njemačke i Ujedinjenog Kraljevstva (UK) taj je postotak i viši $(57-58 \%)$. Ako je točno da plaće u Hrvatskoj ne odražavaju dobro razlike u postignućima, onda je teško i očekivati da će motiv za postignućem predviđati visinu plaće. Ipak, kako bi se mogli donijeti jasniji zaključci, dobiveni se nalazi trebaju replicirati i u budućim istraživanjima na uzorcima reprezentativnijim za hrvatske radnike.

\section{Nedostaci istraživanja}

Kao glavni nedostatak treba istaknuti prigodnost uzorka koji smo koristili, što je dovelo do neravnomjerne distribucije spolova (79\% žena) te velikog broja sudionika s poslijediplomskim obrazovanjem (24\%) i ugovorom na neodređeno $(80 \%)$. No iako ova zadnja dva podatka govore o nereprezentativnosti uzorka, oni su posljedica toga što smo ciljano pokušali uključiti dovoljan broj rukovoditelja kako bismo uopće mogli koristiti kriterij zauzimanja rukovodeće pozicije u našim analizama. Po ostalim karakteristikama bitnim za reprezentativnost u ovom kontekstu, sektoru zaposlenja i veličini organizacije, sudionici su bili ravnomjerno raspoređeni. Osim toga, korelacije osobina petofaktorskog modela s indikatorima karijerne uspješnosti pokazale su slične obrasce kao i u metaanalizama (Ng i sur., 2005) jer su i u našem istraživanju najviše povezanosti s objektivnim indikatorima karijerne uspješnosti imale ekstraverzija i emocionalna stabilnost. Stoga specifičnosti uzorka vrlo vjerojatno nisu utjecale na vezu ličnosti i radnih ishoda.

Drugi je bitan nedostatak ovog istraživanja činjenica da smo karijernu uspješnost odmjerili samo objektivnim indikatorima plaće i rukovodeće pozicije. Uz dva objektivna indikatora koja smo koristili moguće je koristiti i neke druge, npr. godine vožnje bez nesreća za vozača autobusa, broj preživjelih pacijenata za liječnika u hitnoj službi (Heslin, 2005), broj objavljenih radova i citiranost za uspjeh 
znanstvenika (Judge, Kammeyer-Mueller i Bretz, 2004). Međutim, ovakvi su indikatori teško primjenjivi na tip uzorka koji obuhvaća različita zanimanja, kao što je naš. Važnim nedostatkom smatramo i to što smo obuhvatili samo objektivnu, a ne i subjektivnu komponentu karijernog uspjeha, koju većina istraživača u području karijerne uspješnosti smatra značajnom za potpuno zahvaćanje ovog konstrukta (Heslin, 2005). Istraživanja pokazuju da iako su dvije komponente pozitivno povezane, ova je povezanost srednje visoka (Judge i sur., 1995), a mnogi pojedinci koji su objektivno uspješni u karijeri ne percipiraju se uspješnima (Korman, WittigBerman i Lang, 1981). Iako se po nekim autorima čak i intrinzična motivacija za posao može smatrati oblikom subjektivne karijerne uspješnosti (Heslin, 2005), buduća bi istraživanja svakako trebala jasnije ispitati važnost motiva za postignućem i moći za objašnjavanje subjektivnog doživljaja uspješnosti i zadovoljstva vlastitom karijerom općenito (npr. Greenhaus, Parasuraman i Wormley, 1990).

\section{Implikacije}

Naši su rezultati pokazali kako su motivi za postignućem i moći bitni za predviđanje pozitivnih radnih ishoda, čak i u odnosu na trenutno dominantni model ličnosti - petofaktorski model. Osim što su se ovi motivi pokazali važnima za predviđanje objektivnih indikatora karijerne uspješnosti, pokazali su se važnima i za predviđanje intrinzične motivacije za posao, što je odnos koji je do sada slabo istraživan u području psihologije rada i organizacijske psihologije. Razlog njihove važnosti vjerojatno leži u činjenici da su ova dva motiva po samoj definiciji uže povezani $\mathrm{s}$ radnim kontekstom od dosta opširnih $\mathrm{i}$ heterogenih osobina petofaktorskog modela (Hough, 1992). Na primjer, većina je težnji koje čine motiv za postignućem povezana s izvršavanjem zadataka i razvojem vještina, a odrasle osobe ove će težnje najlakše zadovoljiti u sklopu svog posla. Također, motiv za moći čini snažna potreba za vođenjem i usmjeravanjem drugih, a upravo u sklopu organizacije $u$ kojoj rade pojedinci imaju najveću mogućnost da dođu na poziciju u kojoj su hijerarhijski nadređeni drugima. Stoga se čini da u radnom kontekstu ovi motivi imaju potencijal za preciznije predviđanje radnih ishoda u odnosu na petofaktorski model. Buduće studije trebaju to potvrditi i za druge ishode, a ne samo dva objektivna indikatora karijerne uspješnosti mjerena ovdje i intrinzičnu motivaciju za posao.

Također, kao što smo već naveli, ovo istraživanje ima specifične implikacije za hrvatsku psihologiju rada i organizacijsku psihologiju jer je prvo koje je ispitalo važnost ličnosti za objektivno odmjerenu karijernu uspješnost. Dobiveni su nalazi pokazali da su unatoč razlikama u kvaliteti radnog života između hrvatske i razvijenih zapadnih ekonomija (Šverko i Galić, 2014) individualne razlike u motivima povezane sa zauzimanjem rukovodeće pozicije i visinom plaće i u hrvatskom kontekstu. Osim toga, koliko znamo, prvi smo uopće ispitivali intrinzičnu motivaciju za posao na hrvatskom uzorku. Buduća bi istraživanja svakako trebala potvrditi mogu li se naši nalazi replicirati na uzorcima reprezentativnijim za hrvatske 
radnike, koristeći druge mjere osobina petofaktorskog modela, motiva za moći i postignućem te karijerne uspješnosti i intrinzične motivacije za posao.

\section{Zaključak}

U nedavnom su pregledu 100 godina istraživanja individualnih razlika u području psihologije rada i organizacijske psihologije Sackett i suradnici (2017) iskazali iznenađenost činjenicom da su otkrili mnogo starijih istraživanja koja su se bavila temama koje su i danas relevantne i zanimljive. Smatramo kako uloga motiva za postignućem i moći za predviđanje radnih ishoda predstavlja jednu od takvih tema. U ovom smo radu pokazali kako su ova dva motiva važna determinanta radnih ishoda hrvatskih radnika, povrh dominantnog petofaktorskog modela ličnosti. Pri tome je motiv za postignućem bio važnija determinanta intrinzične motivacije za posao, a motiv za moći plaće i posla na višim razinama organizacijske hijerarhije.

\section{Literatura}

Aiken, L. S. i West, S. G. (1991). Multiple regression: Testing and interpreting interactions. Newbury Park, CA: Sage.

Barrick, M. R., Mount, M. K. i Judge, T. A. (2001). Personality and performance at the beginning of the new millennium: What do we know and where do we go next? International Journal of Selection and Assessment, 9(1\&2), 9-30.

Bipp, T., Steinmayr, R. i Spinath, B. (2008). Personality and achievement motivation: Relationship among Big Five domain and facet scales, achievement goals, and intelligence. Personality and Individual Differences, 44(7), 1454-1464.

Carbonneau, N., Vallerand, R. J. i Lafrenière, M. A. K. (2012). Toward a Tripartite Model of intrinsic motivation. Journal of Personality, 80(5), 1147-1178.

Costa, P. T. i McCrae, R. R. (1992). Revised NEO Personality Inventory (NEO-PI-R) and NEO Five-Factor Inventory (NEO-FFI) professional manual. Odessa, FL: Psychological Assessment Resources.

Dillman, D. A. (2007). Mail and internet surveys - the tailored design method, 2nd ed. New York: Wiley.

Donnellan, M. B., Oswald, F. L., Baird, B. M. i Lucas, R. E. (2006). The mini-IPIP scales: Tiny-yet-effective measures of the Big Five factors of personality. Psychological Assessment, 18(2), 192-203.

Drasgow, F. (1988). Polychoric and polyserial correlations. U: L. Kotz i N. L. Johnson (Ur.), Encyclopedia of statistical sciences (Vol. 7, str. 69-74). New York: John Wiley.

Dudley, N. M., Orvis, K. A., Lebiecki, J. E. i Cortina, J. M. (2006). A meta-analytic investigation of conscientiousness in the prediction of job performance: Examining the intercorrelations and the incremental validity of narrow traits. Journal of Applied Psychology, 91(1), 40-57. 
Elliot, A. J. i Harackiewicz, J. M. (1996). Approach and avoidance achievement goals and intrinsic motivation: A mediational analysis. Journal of Personality and Social Psychology, 70(3), 461-475.

Erez, A. i Judge, T. A. (2001). Relationship of core self-evaluations to goal setting, motivation, and performance. Journal of Applied Psychology, 86, 1270-1279.

Eurofund. (2015). Šesto Europsko istraživanje o radnim uvjetima. Luxembourg: Office for Official Publications of the European Communities.

Frieze, I. H., Olson, J. E., Murrell, A. J. i Selvan, M. S. (2006). Work values and their effect on work behavior and work outcomes in female and male managers. Sex Roles, 54(12), 83-93.

Gagne, M. i Deci, E. L. (2005). Controlling shareholders and corporate governance: Complicating the comparative taxonomy. Journal of Organizational Behavior, 26(4), 331-362.

Gagné, M., Forest, J., Vansteenkiste, M., Crevier-Braud, L., van den Broeck, A., Aspeli, A. K., ... Westbye, C. (2015). The Multidimensional Work Motivation Scale: Validation evidence in seven languages and nine countries. European Journal of Work and Organizational Psychology, 24(2), 178-196.

Goldberg, L. R. (1990). An alternative "description of personality": The Big Five Factor structure. Journal of Psychology and Social Psychology, 59(6), 1216-1229.

Greenhaus, J. H., Parasuraman, S. i Wormley, W. M. (1990). Effects of race on organizational experiences, job performance evaluations, and career outcomes. Academy of Management Journal, 33, 64-86.

Heslin, P. A. (2005). Conceptualizing and evaluating career success. Journal of Organizational Behavior, 26, 113-136.

Hough, L. M. (1992). The 'Big Five' personality variables-construct confusion: Description versus prediction. Human Performance, 5(1\&2), 139-155.

Howard, A. i Bray, D. (1988). Managerial lives in transition: Advancing age and changing times. New York: Guilford Press.

Judge, T. A., Bono, J. E., Ilies, R. i Gerhardt, M. W. (2002). Personality and leadership: A qualitative and quantitative review. Journal of Applied Psychology, 87(4), 765-780.

Judge, T. A., Cable, D. M., Boudreau, J. W. i Bretz, R. D. (1995). An empirical-investigation of the predictors of executive career success. Personnel Psychology, 48(3), 485-519.

Judge, T. A., Heller, D. i Mount, M. K. (2002). Five-factor model of personality and job satisfaction: A meta-analysis. Journal of Applied Psychology, 87(3), 530-541.

Judge, T. A. i Ilies, R. (2002). Relationship of personality to performance motivation: A metaanalytic review. Journal of Applied Psychology, 87(4), 797-807.

Judge, T. A., Kammeyer-Mueller, J. i Bretz, R. D. (2004). A longitudinal model of sponsorship and career success: A study of industrial-organizational psychologists. Personnel Psychology, 57(2), 271-303. 
Kanfer, R., Frese, M. i Johnson, R. E. (2017). Motivation related to work: A century of progress. Journal of Applied Psychology, 102(3), 338-355.

Korman, A. K., Wittig-Berman, U. i Lang, D. (1981). Career success and personal failure: Alienation in professionals and managers. Academy of Management Journal, 24(2), 342-360.

Maslić Seršić, D. i Tomas, J. (2014). The role of dispositional employability in determining individual differences in career success. Društvena istraživanja, 23(4), 593-613.

McClelland, D. C. (1987). Human motivation. New York: Cambridge University Press.

McClelland, D. C. i Boyatzis, R. E. (1982). Leadership motive pattern and long-term success in management. Journal of Applied Psychology, 67(6), 737-743.

McClelland, D. C. i Franz, C. E. (1992). Motivational and other sources of work accomplishments in mid-life: A longitudinal study. Journal of Personality, 60(4), 679707.

McClelland, D. C. i Burnham, D. H. (2003). Power is the great motivator. Harvard Business Review, 81(1), 117-126.

Miner, J. B. (1978). Twenty years of research on Role-motivation theory of managerial effectiveness. Personnel Psychology, 31(4), 739-760.

Mischel, W. (1968). Personality and assessment. London, UK: Wiley

Ng, T. W. H., Eby, L. T., Sorensen, K. L. i Feldman, D. C. (2005). Predictors of objective and subjective career success: A meta-analysis. Personnel Psychology, 58, 367-408.

Phillips, J. M. i Gully, S. M. (1997). Role of goal orientation, ability, need for achievement, and locus of control in the self-efficacy and goal-setting process. Journal of Applied Psychology, 82(5), 792-802.

Rawsthorne, L. J. i Elliot, A. J. (1999). Achievement goals and intrinsic motivation: A metaanalytic review. Personality and Social Psychology Review, 3(4), 326-344.

Roberts, B. W., Kuncel, N. R., Shiner, R., Caspi, A. i Goldberg, L. R. (2007). The power of personality: The comparative validity of personality traits, socioeconomic status, and cognitive ability for predicting important life outcomes. Perspectives on Psychological Science, 2(4), 313-345.

Sackett, P. R., Lievens, F., Van Iddekinge, C. H. i Kuncel, N. R. (2017). Individual differences and their measurement: A review of 100 years of research. Journal of Applied Psychology, 102(3), 254-273.

Schönbrodt, F. D. i Gerstenberg, F. X. R. (2012). An IRT analysis of motive questionnaires: The Unified Motive Scales. Journal of Research in Personality, 46, 725-742.

Seibert, S. E., Grant, J. M. i Kraimer, M. L. (1999). Proactive personality and career success. Journal of Applied Psychology, 84(3), 416-426.

Stahl, M. J. (1983). Achievement, power, and managerial motivation: Selecting managerial talent with the job choice experience. Personnel Psychology, 36, 775-789.

Steinmann, B., Otting, S. K. i Maier, G. W. (2016). Need for affiliation as a motivational addon for leadership behaviors and managerial success. Frontiers in Psychology, 7, 1-18. 
Šverko, B. i Galić, Z. (2014). The perceived quality of working life in Croatia and the European Union. Društvena istraživanja: Časopis za opća društvena pitanja, 23(4), 557-575.

Winter, D. G., John, O. P., Stewart, A. J., Klohnen, E. C. i Duncan, L. E. (1998). Traits and motives: Toward an integration of two traditions in personality research. Psychological Review, 105(2), 230-250.

Wu, J. i LeBreton, J. M. (2011). Reconsidering the dispositional basis of counterproductive work behavio: The role of aberrant personality. Personnel Psychology, 64(3), 593-626.

Yukl, G. (2008). How leaders influence organizational effectiveness. The Leadership Quarterly, 19(6), 708-722.

Yukl, G. i Falbe, C. M. (1991). Importance of different power sources in downward and lateral relations. Journal of Applied Psychology, 76(3), 416-423.

\title{
The Importance of the Achievement Motive and the Power Motive for Explaining the Occupancy of a Management Position, Salary and Intrinsic Work Motivation
}

\begin{abstract}
In this study, the focus of the research was shifted back to the two individual difference characteristics that were, before the appearance of the five-factor model, considered as key determinants of work and career outcomes next to intelligence: the achievement motive and the power motive. It was examined whether the two motives will predict three important work outcomes: occupancy of a management position, salary and intrinsic work motivation, over and above the five-factor model traits. The occupancy of a management position was operationalized as working at higher levels of organizational hierarchy and salary was operationalized as the amount of monthly net salary. Intrinsic work motivation was measured with a self-report questionnaire. The study was conducted on 160 employees of various Croatian work organizations and data was collected through an online survey. The correlational and regression analyses showed that the achievement motive and the power motive were important determinants of the work outcomes, explaining them better than the five-factor model traits. The achievement motive showed to be more important for intrinsic work motivation, whereas the power motive was more important for management position and salary. These findings show that individual difference characteristics which are more closely related to the work context, such as the achievement motive and the power motive, have considerable incremental validity and should be considered alongside the broad dimensions of the five-factor model in order to improve the prediction of work outcomes.
\end{abstract}

Keywords: achievement motive, power motive, five-factor model of personality, management position, salary, intrinsic work motivation

Primljeno: 20.3.2018. 